\title{
Relation of glacier variations to climate changes in Iceland
}

\author{
ODDUR SIGURDSSON \\ National Energy Authority, Grensásvegi 9, IS-108 Reykjavik, Iceland \\ Trausti Jónsson \\ Icelandic Meteorological Office, Bústadavegi 9, IS-150 Reykjavik, Iceland
}

\begin{abstract}
Glacier variations in Iceland have been recorded systematically since the 1930s at 27 different glacier termini. The advance/retreat records of nonsurging glaciers show a clear relationship to climate. A change in the climate typically leads to a response at the snout within a time period of 10 years. The records of surgetype and mixed-type glaciers show variations that are unrelated to climate. However, the maximum extension of surge-type glaciers at the end of surges and the minimum extension just before a surge appear to be influenced by long-term climate changes. A strong warming in the 1920 s was a turning-point in the climate of Iceland which led to a rapid retreat of most glaciers in the country in the 1930 s. The summer temperature fell gradually after 1940 , with a notable drop in the mid-1960s. Since about 1970 , more than half of the glaciers in Iceland have been advancing. In the western part of the country, the recovery is about one-quarter of the ground lost and in the southern, central and northern parts it is about one-half. In southeastern Iceland, some of the glaciers have been stationary for about 30 years while others have advanced slightly. Glacier snow-budget index computed from meteorological data indicates that the timing of the turning-point around 1970 coincides with a minimum in the cumulative net glacier mass balance.
\end{abstract}

\section{INTRODUCTION}

Glaciers in Iceland cover about $11000 \mathrm{~km}^{2}$, or about $11 \%$ of the area of the country (Fig. 1) (Björnsson, 1978). The glaciers are of many different types, ranging from small cirque glaciers to extensive plateau ice caps. All glaciers in
Iceland are temperate. Four large ice caps, each with many outlet glaciers, constitute over $95 \%$ of the total glaciated area, but smaller ice caps, valley glaciers and cirque glaciers cover a total of about $500 \mathrm{~km}^{2}$.

The climate of Iceland is oceanic, characterized by relatively warm winters but cool summers. The average

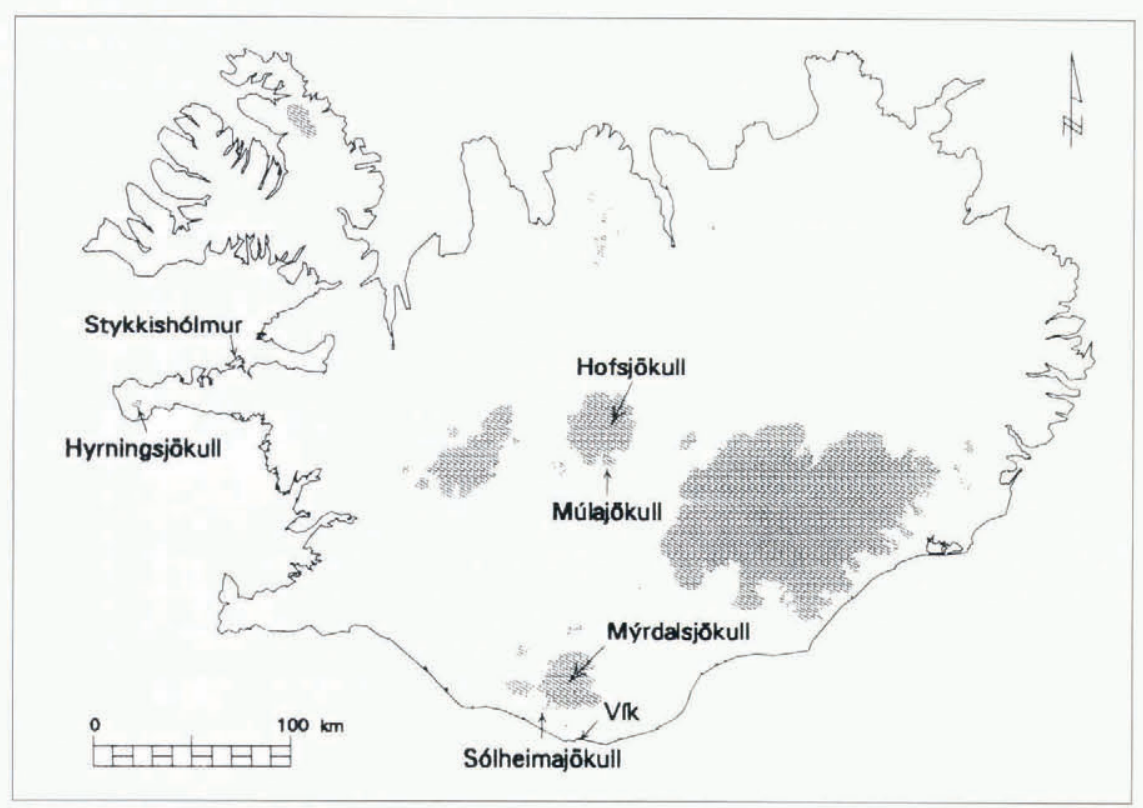

Fig. 1. Location map showing the glaciers and the weather slations mentioned in the text. 


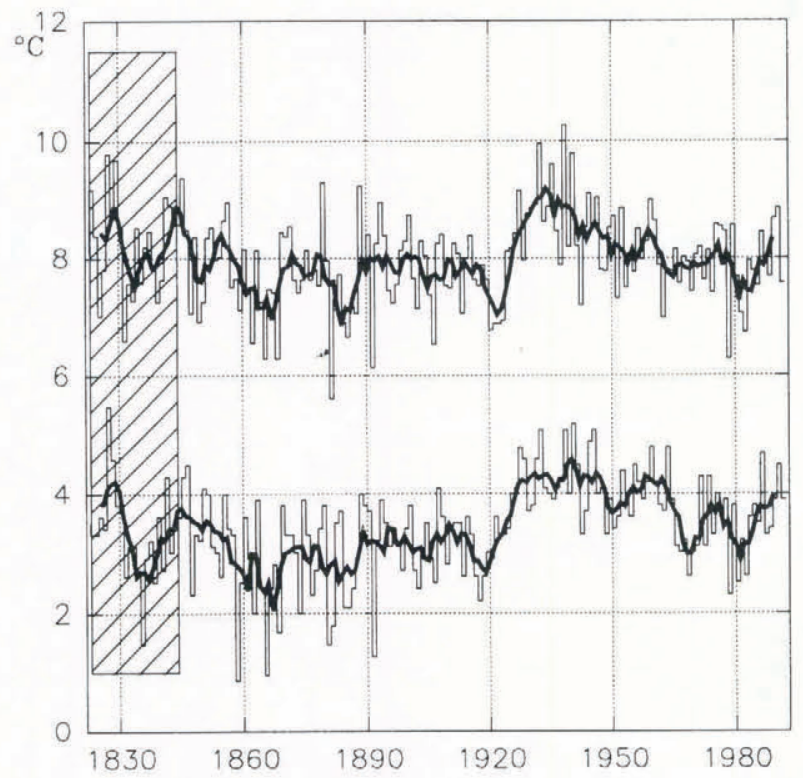

Fig. 2. Tearly mean lemperature (lower) and summer temperature (May-September)(upper)at the Stykkisho'mur meteorological station, western Iceland (histogram). Solid curves show 5 a running means, using equal weights. Values in the box are inferred from another location (Reykjavik, 1823-45).

January temperature is about $0^{\circ} \mathrm{C}$ in the southern lowlands, but about $-2^{\circ} \mathrm{C}$ at the northern coast. Inland temperatures are lower. Most of the non-coastal lowlands have an average July temperature slightly above $10^{\circ} \mathrm{C}$, but at the northern coast the average July temperature is about $8^{\circ} \mathrm{C}$.

Easterly winds come closest to typifying the prevalent wind direction over most of the country. Southerly winds typically bring the largest amount of precipitation, with the highest annual values occurring on the southeastern coast, where the annual mean exceeds $3000 \mathrm{~mm}$ in the lowlands. Considerably more precipitation falls on the mountains and glaciers in that region. The driest climate is found in the northern inland region, where the average yearly precipitation is below $400 \mathrm{~mm}$.

A continuous temperature record exists from Iceland since 1822 (Fig. 2). Its most outstanding feature is a warming in the 1920 s after a very cold period of 70 years. Another notable feature is a cooling in the mid-1960s.

Many Icelandic glaciers attained their historical maximum extension in the latter part of the 19th century (Björnsson, 1979).

\section{GLACIER VARIATIONS IN ICELAND}

Glacier variations at 27 glacier snouts in Iceland have been monitored since the 1930s (Eythorsson, 1931, 1935, 1963). Monitoring of 11 additional snouts started during the period 1948-72. Since 1951, these measurements have been carried out by the Icelandic Glaciological Society and reported annually in the periodical fökull (e.g. Sigurdsson, 1992). The position of the terminus is measured by tape from stakes or cairns during the autumn or early winter.

The glaciers vary greatly in size and form. The biggest outlet glacier is $1500 \mathrm{~km}^{2}$, the smallest valley glacier less than $1 \mathrm{~km}^{2}$. Their length varies from 1 to $50 \mathrm{~km}$. The greatest altitude range of a single glacier is nearly $2000 \mathrm{~m}$. Mean yearly precipitation varies from 500 to $3000 \mathrm{~mm} \mathrm{a}^{-1}$ at the snout and reaches a maximum of about 6000 $\mathrm{mma}^{-1}$ at the top of some of the glaciers.

Six of the 27 glaciers monitored since the 1930s are surge-type glaciers and five are of mixed or unknown character. Some glaciers which show an obviously quick response to climate changes also feature surges, but these surges tend to be on a smaller scale. Some broad outlet glaciers are composed of two or more parallel streams which may surge independently.

The period 1930 60 was characterized by a very fast retreat of all monitored glacier fronts, occasionally interrupted by short surges or surge-like advances. In 1962, all monitored glaciers in Iceland without exception had retreated from their 1930 position. The retreat rate of many levelled off around 1960, and many glaciers started to advance after 1970 . A few have been stationary since then. The fastest advance has been observed for glaciers in southern, central and northern Iceland, which have recovered about half of the ground lost since 1930. A glacier in western Iceland has recovered about one-

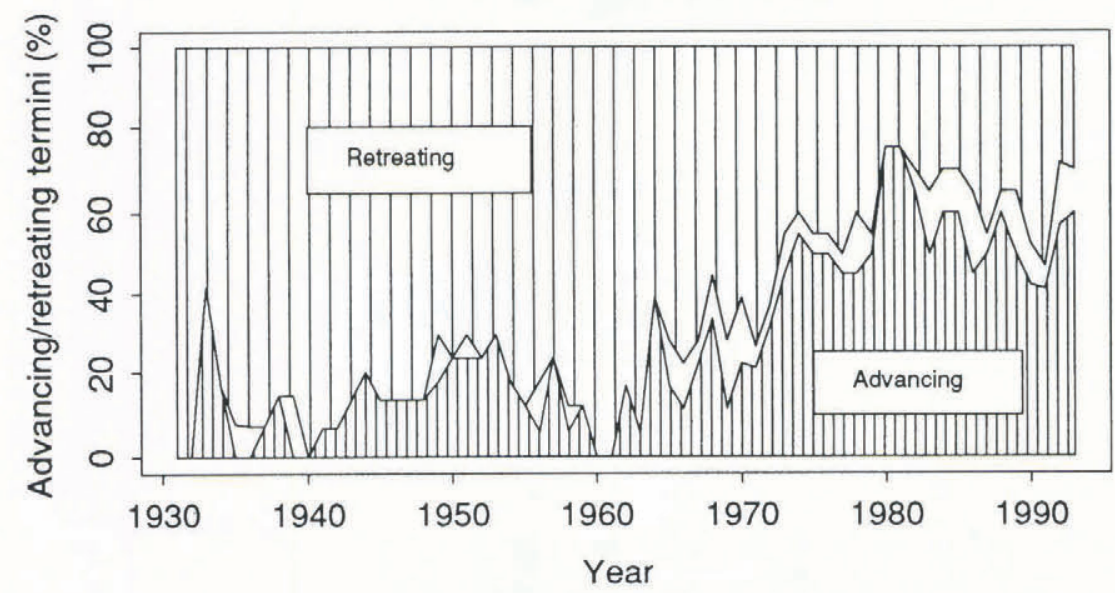

Fig. 3. Glacier fluctuation in Iceland 1930 93. Percentage of advancing (dense shading) and retreating (less dense shading) non-surging glaciers relative to the total number of monitored glaciers. 
quarter of its lost ground, but many glaciers in southeastern Iceland have been almost stationary, and two glaciers there have continued retreating at a slow rate. Figure 3 shows the percentage of advancing and retreating non-surging glaciers as a function of time from $1930 / 31$ to $1992 / 93$. The turning-point around 1960 is evident from the figure.

Temperature changes have been the most important driving factor for the glacier variations. Mean summer temperature in Iceland rose by approximately $0.6^{\circ} \mathrm{C}$ from the first to the second quarter of this century according to the records of the Icelandic Meteorological Office (Fig. 2).The climate generally cooled between 1940 and 1980, but the temperature has risen slowly since. This is concordant with observed temperature variations in the Northern Hemisphere which show high temperatures between 1925 and 1960 and a local cooling in the northwest Atlantic between 1960 and 1990 (Chapman and Walsh, 1993). During the last 60 years, there has been no apparent trend in precipitation in Iceland according to the records of the Icelandic Meteorological Office.

The rapid retreat of glaciers in Iceland during the 1930 s (cf. Fig. 3) was caused by a reduction in the glacier mass balance due to the rise in the temperature in the 1920 s (cf. Fig. 2).The terminus response of the glaciers therefore occurred within 5-10years of the change in temperature. The timing of first response of the nonsurging glaciers does not seem to depend much on the type or size of the glacier. Large outlet and valley glaciers and small cirque glaciers all retreat rapidly within 5 10 years of the warming of the climate. Furthermore, the timing of the minimum extension of the glaciers does not depend on the length of the glacier, as is evident from Figure 4.

The reversal of the Icelandic glaciers around 1960 shows a pattern similar to that observed in other parts of the world. Wood (1988) finds, on the basis of World Glacier Monitoring Service records, that the world's alpine glaciers have shifted from a regime strongly dominated by recession to one more characterized by advance. The rapid response of the Icelandic glaciers is in

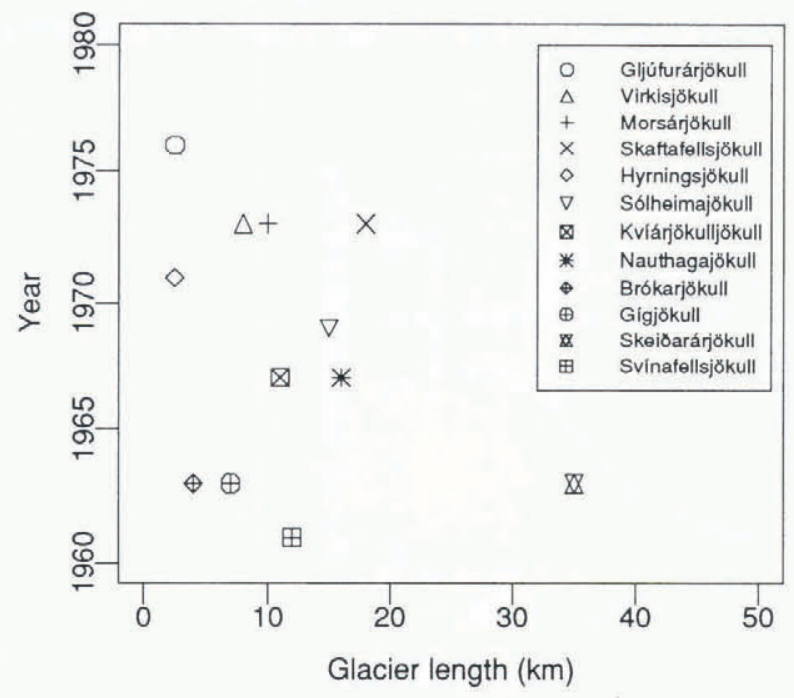

Fig. 4. Length of non-surging glaciers plotted against year of minimum extent. line with observations from other areas. As an example, the measurements described in Armstrong (1989) show that the terminus of Blue Glacier, northwestern U.S.A., reacts within a few years of a change in the mass balance.

\section{RESPONSE OF GLACIERS TO CHANGES IN MASS BALANCE}

Reconstructions of glacier variations from geological evidence or historical observations are a valuable source of information about the climate of the past. In order to interpret glacier variations in terms of climate changes, one must take account of a time lag between a change in the climate and a resulting change in the extension of the glaciers. The Icelandic glacier-variation data set covers a period of significant climate changes, and one may identify a clear response of the glaciers to the climate changes.

The response time of glaciers is defined as the time constant in an exponential asymptotic approach to a final steady state after a sudden change to a new constant climate. The response time may be roughly estimated as the ratio of a scale of thickness of the glacier to a scale of the negative of mass balance at the terminus (Jóhannesson and others, 1989). This estimate gives response times of 10-100years for typical temperate glaciers. Thin glaciers with high ablation at the terminus have the shortest response times according to this estimate. Thus, one would expect steep glaciers with a great elevation range to adjust relatively quickly to climate changes.

A lower limit to the response time may be obtained by examining how long glaciers continue to advance/retreat after a climatic change has occurred. The Icelandic glaciers retreated for about 30 years after a sudden warming, although the climate showed a slow cooling trend over this interval. This indicates that the response time of the glaciers is longer than or equal to approximately 30 years.

\section{THREE EXAMPLES FROM THE ICELANDIC GLACIER-VARIATIONS DATA SET}

\subsection{Sólheimajökull}

Mýrdalsjökull is a $590 \mathrm{~km}^{2}$ ice cap in southern Iceland, and Sólheimajökull (Fig. 5 ) is a valley glacier $10 \mathrm{~km}$ long that drains $110 \mathrm{~km}^{2}$ of the southern part of the ice cap (personal communication from H. Björnsson, 1994). The glacier spans an altitude range of $100-1500 \mathrm{ma}$ a.s.l. The average surface slope is 0.10 . Precipitation has been reported to range from $3200 \mathrm{mma}^{-1}$ at the snout to $4000 \mathrm{mma}^{-1}$ at the top (Sigfúsdóttir, 1964). Runoff measurements indicate somewhat higher precipitation, perhaps reaching $6000 \mathrm{mma}^{-1}$ or more at the higher elevations (Sigurdsson, 1990). The thickness scale for the glacier is about $300 \mathrm{~m}$ (mean thickness $225 \mathrm{~m}$ ) and the scale for the mass balance at the snout is $-12 \mathrm{~m}$. Accordingly, the response time of the glacier can be estimated to be about 25 years.

The snout of Sólheimajökull has been measured every year since 1930 except for 1942, 1946 and 1957. Figure 6 


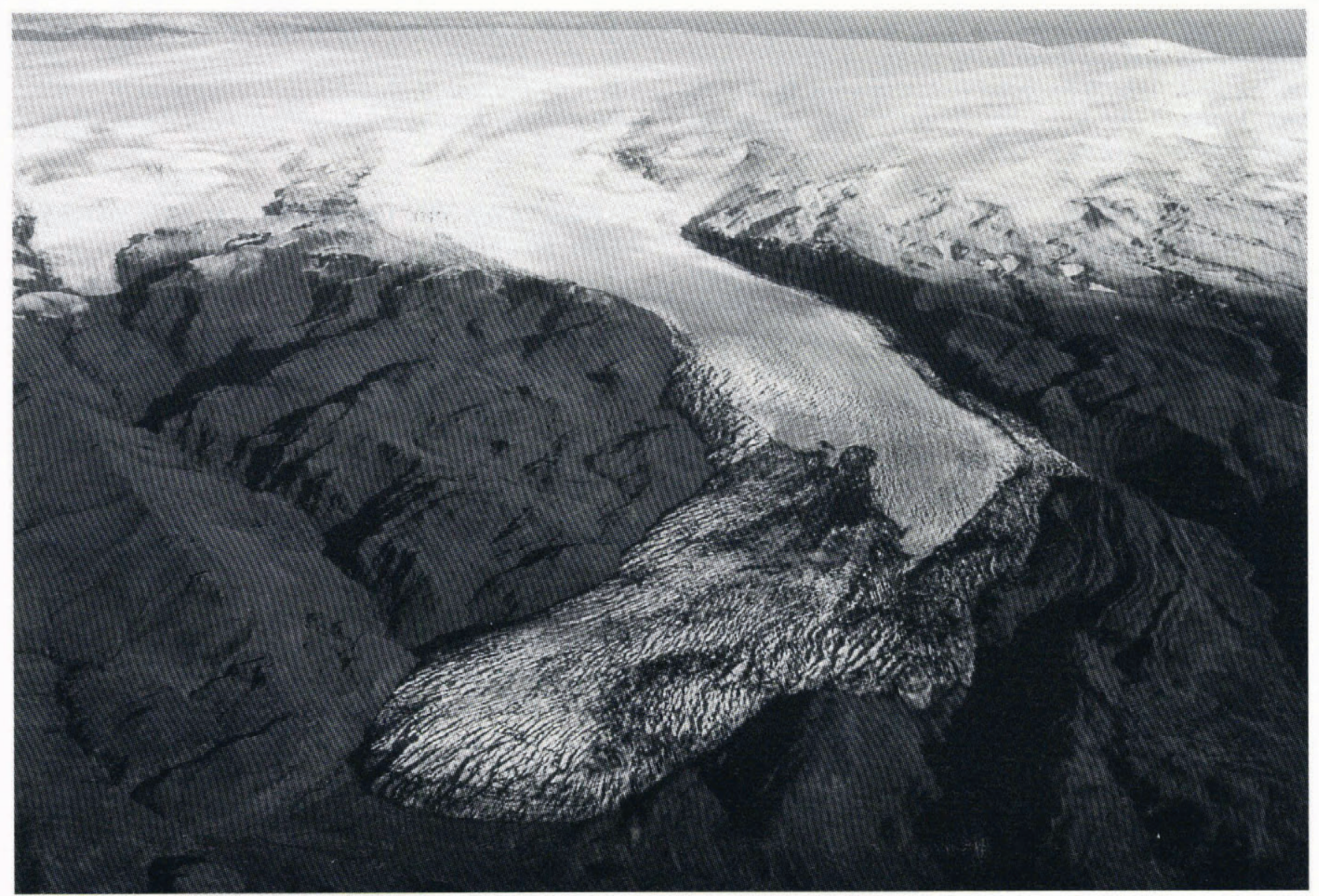

Fig. 5. Sótheimajökull, southern Iceland, a valley glacier which flows from a volcanic caldera in the Mýrdalsjökull ice cap. A system of lateral moraines can be seen alongside the glacier. Photograph by O. Sigurdsson.

shows the terminus variations since 1930. The glacier retreats rapidly for the first 35 years except for a slight advance around 1950 and in 1965. Readings in 1965 and 1966 are ambiguous, but there is no doubt that the glacier advanced between the 1964 and 1965 readings. The magnitude of the yearly variations is typically less than $50 \mathrm{~m}$. The extension of the glacier reached a minimum in 1969 after a retreat of $1 \mathrm{~km}$ in 39 years. Since then, the glacier snout has advanced continuously up to the present, with a slight halt in 1976 and 1979. The terminus has advanced half-way back to where it was in 1930. The rate of advance has been similar to the rate of retreat.

\subsection{Hyrningsjökull}

Snæfellsjökull is a cone-shaped central volcano on the tip of the Snæfellsnes peninsula in western Iceland (Fig. 7). The top reaches $1450 \mathrm{~m}$ a.s.l. A small $\left(13 \mathrm{~km}^{2}\right)$ steep-sided ice cap covers the top of the volcano. The outlet glacier Hyrningsjökull flows eastwards and drains an area of less than $2 \mathrm{~km}^{2}$. The elevation range is $700-1450 \mathrm{~m}$ a.s.l. and the average surface slope is 0.29 . Precipitation at sea level is about $750 \mathrm{~mm} \mathrm{a}^{-1}$ and is estimated to be about $2500 \mathrm{mma}^{-1}$ at the top of the glacier (Sigfúsdóttir, 1964). The thickness scale for the glacier is about $200 \mathrm{~m}$

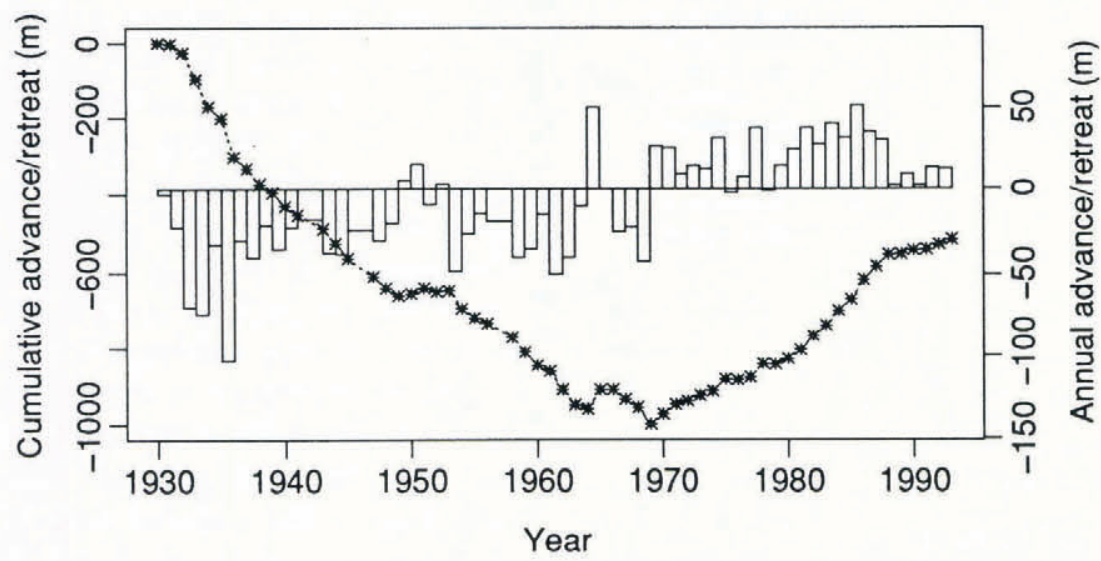

Fig. 6. Terminus fluctuations of Sólheimajökull 1930/31-1992/93 (histogram) and cumulative advance/retreat since 1930 (dashed curve). 


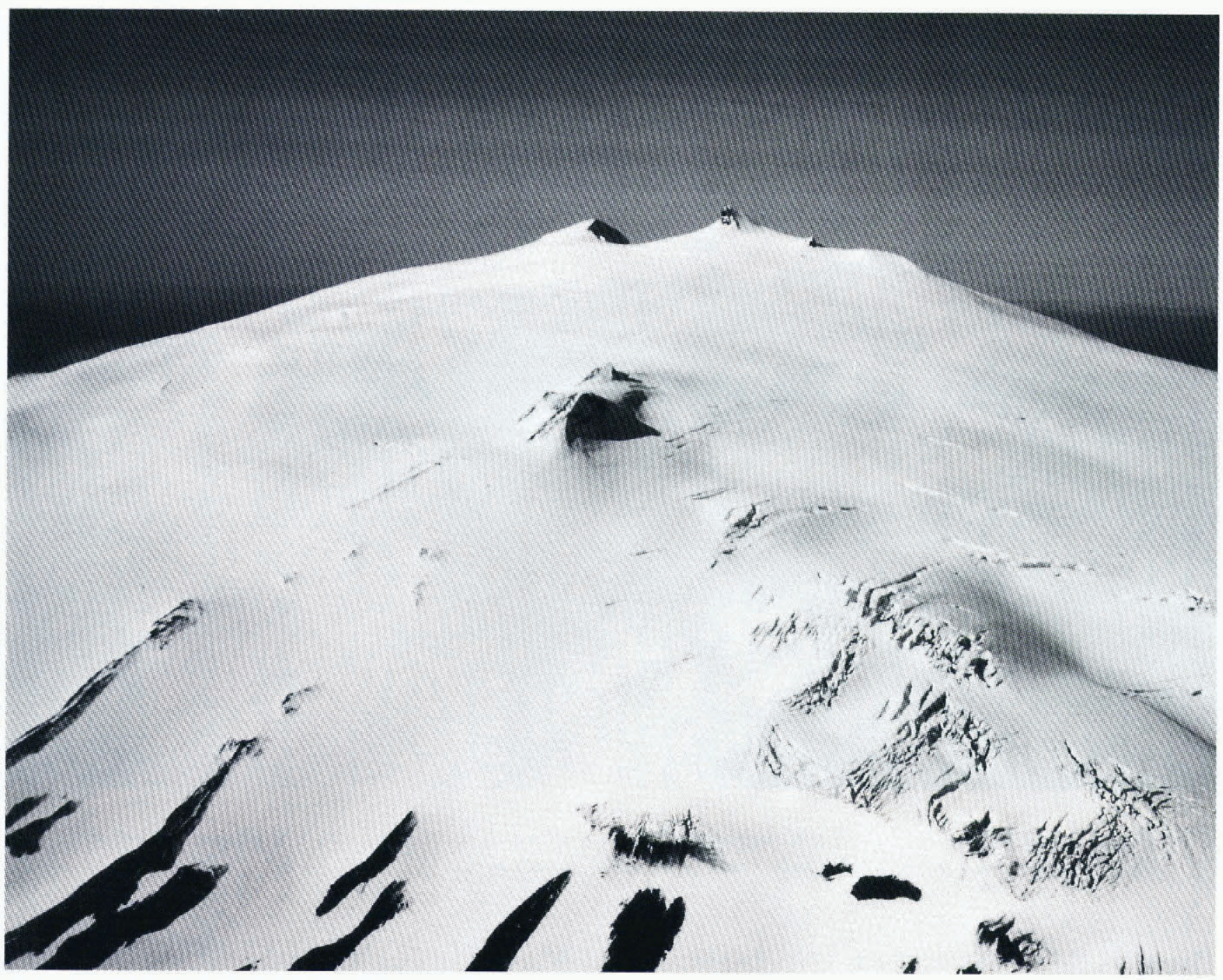

Fig. 7. Hyrningsjökull, western Iceland, a part of the Snafellsjökull ice cap. Photograph by O. Sigurdsson.

(mean thickness is estimated to be about $150 \mathrm{~m}$ ) and the scale for the mass balance at the snout is $-4 \mathrm{~m}$. Accordingly, the response time of the glacier is about 50 years.

Figure 8 shows the terminus variations of Hyrningsjökull since 1931. The location of the snout was measured every year in all but seven years. The retreat rate was rapid during the first 20 years and declined gradually during the following 20 years, and the extension of the glacier reached a minimum in 1971. The glacier has advanced since then, interrupted in 1977 by a slight retreat. Since 1971, the glacier has recovered $250 \mathrm{~m}$ of the $1000 \mathrm{~m}$ retreat between 1931 and 1971 . Annual retreat amounted to more than $70 \mathrm{~m}$ on a few occasions in the $1930 \mathrm{~s}$, while the greatest advance in one year was $34 \mathrm{~m}$ in 1979 , which was the coldest summer of the 20th century.

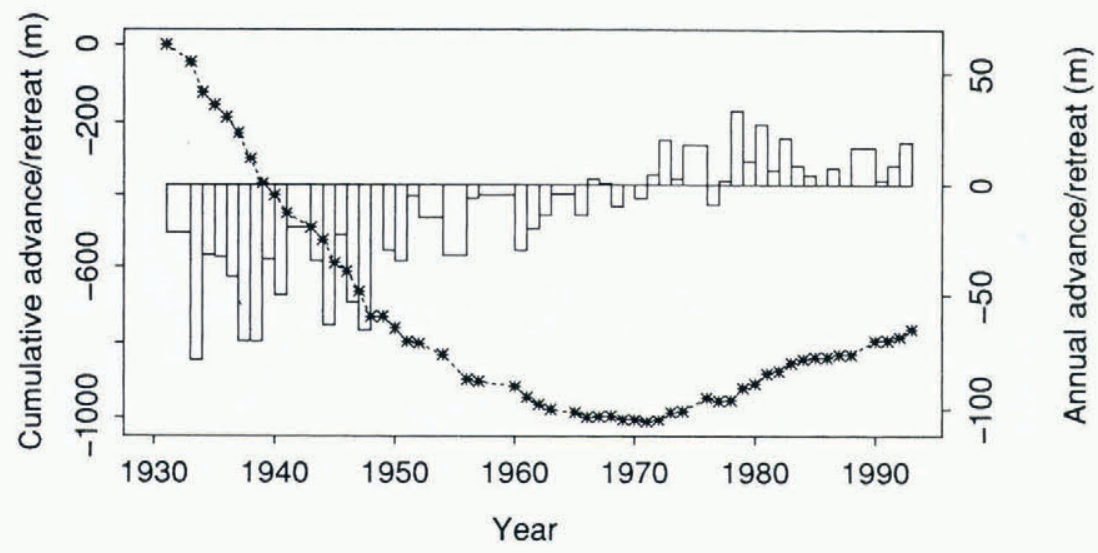

Fig. 8. Terminus fluctuations of Hyrningsjökull 1931/32-1992/93 (histogram) and cumulative advance/retreat since 1931 (dashed curve). 


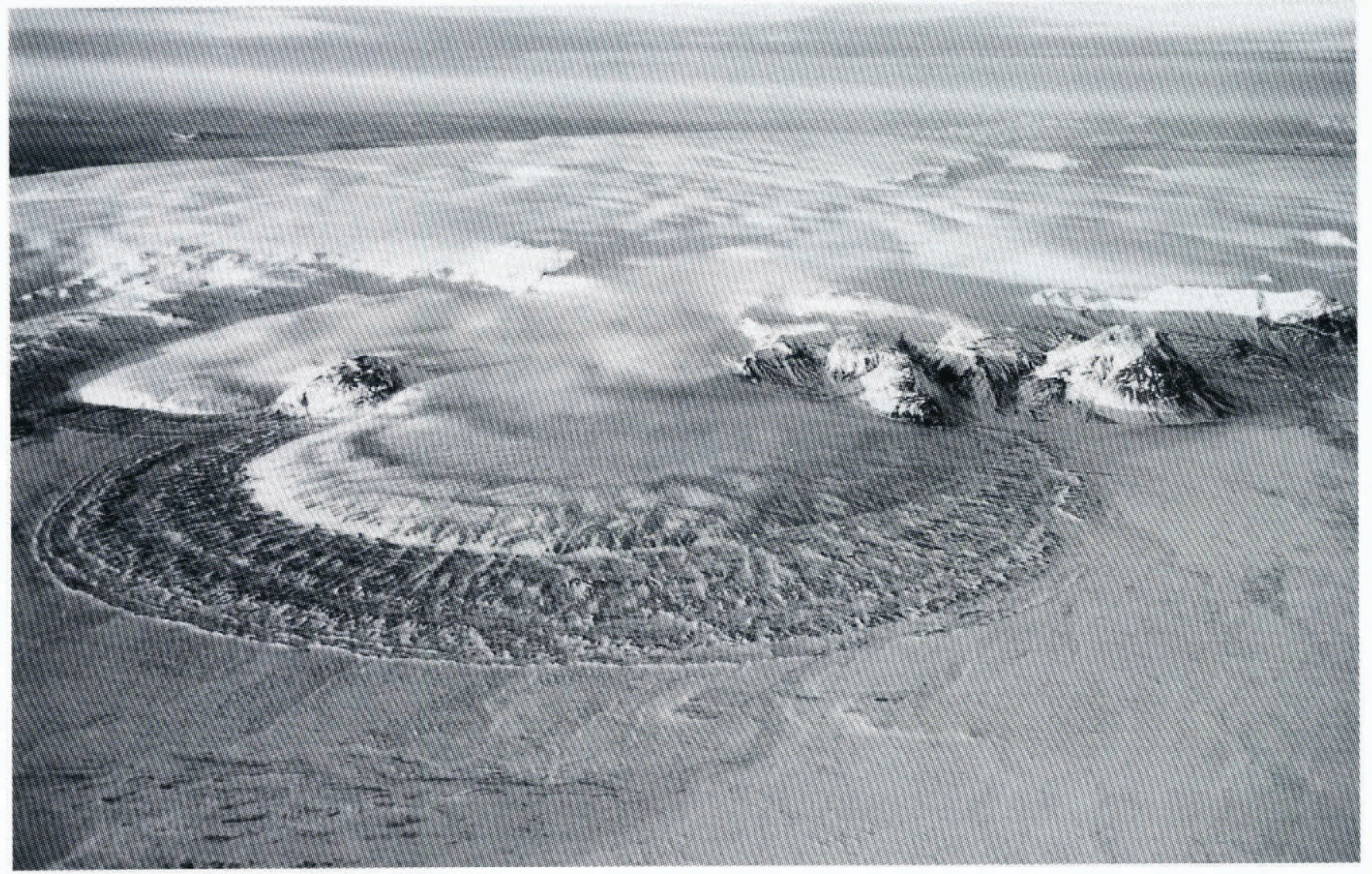

Fig. 9. Múlajökull, central Iceland, a piedmont outlet glacier from the Hofsjökull ice cap. A system of concentric terminal moraines can be seen in front of the glacier. Photograph by O. Sigurdsson.

The rate of advance has been much slower than the rate of retreat.

\subsection{Múlajökull}

Hofsjökull is a $900 \mathrm{~km}^{2}$ ice cap in central Iceland. Múlajökull (Fig. 9) is a piedmont outlet glacier which flows southeastwards and drains $94 \mathrm{~km}^{2}$ of the ice cap (Björnsson, 1988). The elevation range is 610-1800 $\mathrm{m}$ a.s.l. and the average surface slope is 0.06 . Precipitation at the snout is estimated to be $1200 \mathrm{~mm} \mathrm{a}^{-1}$ (Sigfúsdóttir, 1964) and the mean precipitation at the top has been about $4000 \mathrm{~mm} \mathrm{a}^{-1}$ since 1988 (Sigurdsson,
1989, 1991, 1993). Múlajökull is a surge-type glacier which surges frequently with a period of about 10 years. The concept of a response time does not have a welldefined meaning for such glaciers, and we will therefore not estimate the response time of Múlajökull.

Figure 10 shows the terminus variations of Múlajökull since 1932. The location of the snout was measured every year in all but 13 years. The glacier retreated extremely rapidly during the first 10 years. Since then, the retreat has been interrupted five times by surges of $50-400 \mathrm{~m}$ in length. The minimum extent of the glacier was reached in 1969. Since then the glacier has had three major surges. The maximum extent of surges has increased since 1970,

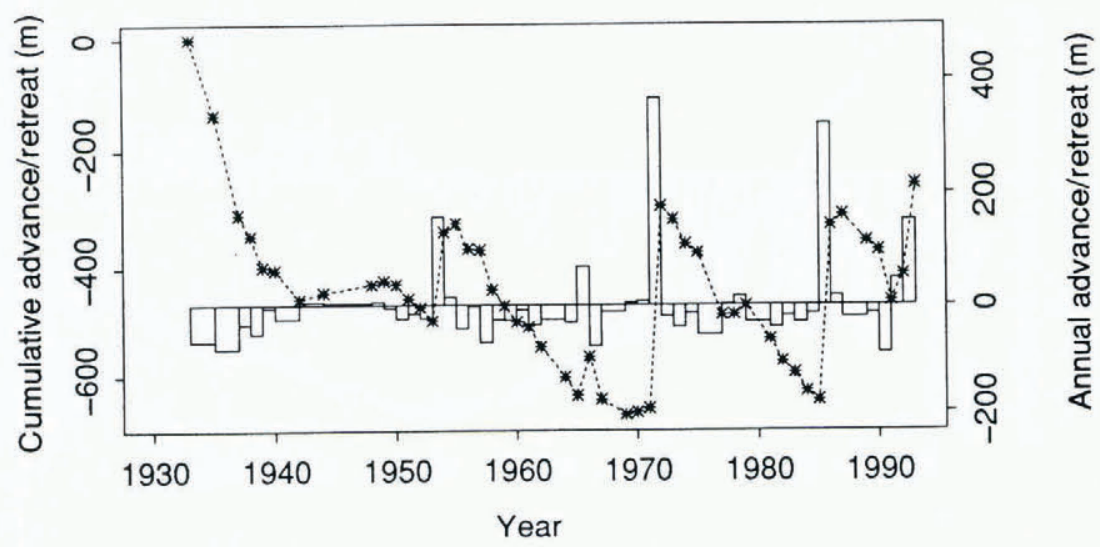

Fig. 10. Terminus fluctuations of Múlajökull, 1932/33-1992/93 (histogram) and cumulative advance/retreat since 1932 (dashed curve). 
while the total retreat between surges has been successively shorter, and in recent years the glacier has regained at least half of the ground lost since 1932. This indicates that surge-type glaciers with a short surge period and non-surge glaciers are affected by climate in a similar manner.

\section{SNOW-BUDGET INDEX}

A simple snow-budget index for Mýrdalsjökull was first described by Tryggvason (1973) and used several times to estimate changes in the ice overburden pressure on the active Katla central volcano unpublished information from H. Jónsson, 1982). The index is derived from monthly precipitation and monthly mean temperature records from the weather station Vík i Mýrdal during 1932-92. The index attempts to estimate the cumulative net mass balance of Mýrdalsjökull as a function of time.

Precipitation measurements began in Vík i Mýrdal in 1925, and temperature measurements in 1926. Before 1932 there are some gaps in the data; as there were no other stations in the vicinity, we have made no attempt to fill these gaps. The Vík station is situated in the lowest part of a valley on the eastern side of a steep, $300 \mathrm{~m}$ high, mountain ridge at the southern tip of Iceland, just south of Mýrdalsjökull. The annual average precipitation exceeds $2000 \mathrm{~mm}$. Another station, Loftsalir, began operating in $1939,7 \mathrm{~km}$ to the west. Precipitation at Loftsalir is considerably less than at Vík, but the relative agreement between the two stations is good. We have therefore estimated the precipitation and temperature during the few gaps after 1932 in the Vík record from the Loftsalir series. There are potential heterogeneities in both series (minor relocations, gauge changes), and no attempt has been made to correct for these.

The snow-budget index is based on the following assumptions:

1. Increase of precipitation with height is such that the amount of precipitation doubles every $800 \mathrm{~m}$.

2. The temperature lapse rate is constant, $-0.65^{\circ} \mathrm{C}$ per $100 \mathrm{~m}$.

3. Monthly melting is proportional to the average monthly temperature, if $T>0^{\circ} \mathrm{C}$.

4. If $T<0^{\circ} \mathrm{C}$ there is no melting.

5. The average net mass balance is zero over the period October 1952-September 1992.

6. The effect of changes in the area and elevation of the ice cap on the net balance is neglected.

7. The total area of Mýrdalsjökull is assumed to be $635.2 \mathrm{~km}^{2}$ (Tryggvason, 1973) and is divided into 13 height intervals of $100 \mathrm{~m}$ each.

The computations result in an estimate of the volume changes of the ice cap which the authors prefer to call an "index" due to the approximate nature of the above assumptions. Glacier mass-balance models based on temperature and precipitation data have been shown to predict measured mass balance of Hofsjökull in Iceland

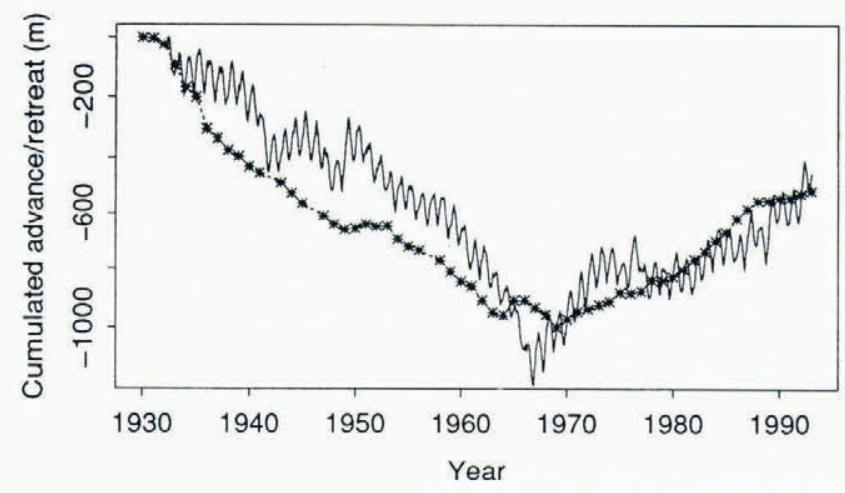

Fig. 11. Cumulative terminus variations of Sótheimajökull, 1930-93 (symbols and dashed curve), and snow-budget index for Vik i Mýrdal, 193292 (solid line) (for explanations, see text).

and of Nigardsbreen in Norway with a fair degree of accuracy (Jóhannesson and others, 1993).

If one assumes that the positions of the termini of the outlet glaciers of Mýrdalsjökull reflect volume changes of the ice cap to some degree, then the snow-budget index should vary in accordance with the terminus variations. Figure 11 shows the cumulative terminus variations of Sólheimajökull, 1930-93 the same as the dashed curve in Figure 6), and the snow-budget index for Vík i Mýrdal, 1932-93. The index is scaled to the length variations of Sólheimajökull in order to facilitate a comparison with the terminus variations. There is general agreement between the two curves. In spite of the gradual cooling from the 1930s onwards, the mass balance remained negative until the 1960s, when the climate had returned to pre1920 s conditions. The timing of the turning-point around 1970 is well predicted by the snow-budget index. Some of the relatively minor changes in the slope of the curves before and after 1970 are similar, although there is some indication that changes in the snow-budget index appear, with a few years' delay, in the terminus variations. Since about 1970, according to the snow-budget index, the glacier has recovered more than half of the mass lost between 1932 and 1970, which is in fair agreement with the glacier variations.

\section{SUMMARY AND CONGLUSION}

Most non-surging glaciers in Iceland have advanced for the last quarter of a century as the result of a general cooling of the climate. There has been no apparent trend in precipitation during the same period. Between 1930 and 1970 , the glaciers had retreated rapidly due to a sudden warming in the 1920 s which led to a relatively warm climate from 1930 to 1960 . The glaciers that have advanced most have recovered half of the ground lost between 1930 and 1970. A few glaciers in the southeastern part of the country have been stationary.

The time lag between a change in climate and the detection of a response at the glacier snout appears to be well within 10 years for most non-surging Icelandic glaciers. The time needed for the glacier to approach a new equilibrium after a sudden change in the climate, i.e. the response time of the glacier, is more difficult to 
estimate from the short Icelandic records, but it appears to be longer than or equal to approximately 30 years. This is not inconsistent with theoretically estimated response times of 25-50 years for the Sólheimajökull and Hyrningsjökull glaciers (cf. Figs 6 and 8).

The terminus variations of Sólheimajökull can be modelled by a very simple snow-budget index based on measured temperature and precipitation at a nearby weather station.

\section{ACKNOWLEDGEMENTS}

We thank the Icelandic Meteorological Office for making its meteorological database available for this study. We thank T. Jóhannesson and an anonymous reviewer for constructive criticism of the paper.

\section{REFERENCES}

Armstrong, R. L. 1989. Mass balance history of Blue Glacier, Washington, USA. In Oerlemans, J., ed. Glacier fluctuations and climatic change. Dordrecht, Kluwer Academic Publishers, 183-192.

Björnsson, H. 1978. The surface area of glaciers in Iceland. Jökull, 28, 31. Björnsson, H. 1979. Glaciers in Iceland. Jökull, 29, 7480.

Björnsson, H. 1988. Hydrology of ice caps in volcanic regions. Vísindafélag Ísl. Rit 45.

Chapman, W. L. and J. E. Walsh. 1993. Recent variations of sea ice and air temperature in high latitudes. Bull. Am. Meteorol. Soc., 74(1), 3347.

Eythorsson, J. 1931. On the present position of the glaciers in Iceland: some preliminary studies and investigations in the summer 1930. Visindafélag isl. Ril 10.

Eythorsson, J. 1935. On the variations of glaciers in Iceland. Geogr. Ann., $17(1-2), 121-137$.

Eythorsson, J. 1963. Variations of Iceland glaciers 1931-1960. Jökull, 13, 31-33.

Jóhannesson, T., C. Raymond and E. Waddington. 1989. Time-scale for adjustment of glaciers to changes in mass balance. 7. Glaciol., 35 (132), $355-369$.

Jóhannesson, T., O. Sigurdsson, T. Laumann and M. Kennett. 1993. Degree-day glacier mass balance modelling with applications to glaciers in Iceland and Nonway. Reykjavík, Orkustofnun. (Nordic Hydrological Programme Rapport 33.

Sigfúsdóttir, A. B. 1964. Nedbör og temperatur i Island. In Islands hydrologi. Reykjavík, Raforkumálastjóri, 112-1-112-17. (4 Nordiske Hydrologkonferanse.

Sigurdsson, F. H. 1990. Vandamál vid úrkomumælingar á Íslandi. In Sigbjarnarson, G., ed. Vatnid og landid, Vatnafradirádstefna, október 1987. Reykjavík, Orkustofnun, 101-110.

Sigurdsson, O. 1989. Afkoma Hofsjökuls 1987-1988. Reykjavík, Orkustofnun. (Report OS-89005/VOD-02B.)

Sigurdsson, O. 1991. Afkoma Hofsjökuls 1988-1989. Reykjavik, Orkustofnun. Report OS-91052/VOD-08 B.)

Sigurdsson, O. 1992. Jöklabreytingar 1930-1960, 1960-1990 og 19901991. Jökull, 42, 81-87.

Sigurdsson, O. 1993. Afkoma nokkurra jökla à Íslandi 1989-1992. Reykjavik, Orkustofnun. (Report OS-93032/VOD-02.

Tryggvason, E. 1973. Surface deformation and crustal structure in the Myrdalsjökull area of south Iceland. J. Geophys. Res., 78(14), 24882497.

Wood, F. B. 1988. Global alpine glacier trends, 1960s-1980s. Arct. Alp. Res., $20(4), 404413$. 